\title{
PEMANFAATAN DATA INSTAGRAM UNTUK MENGETAHUI REPUTASI TEMPAT WISATA DI LOMBOK
}

\author{
Muhammad Azmi'), Amiruddin Khairul Huda ${ }^{2)}$, dan Arief Setiyanto ${ }^{3)}$ \\ ${ }^{1)}$ STMIK Syaikh Zainuddin NW Anjani-Lombok \\ ${ }^{2,3)}$ MTI Universitas Amikom Yogyakarta \\ e-mail: $\underline{\text { muhammad4zmi@gmail.com }}{ }^{1)}, \underline{\text { amirudin.2309@ }}_{\text {students.amikom.ac.id }}{ }^{2}$, $\underline{\text { arief_s@ @amikom.ac.id }}^{3)}$
}

\begin{abstract}
ABSTRAK
Sosial media saat ini memiliki pengaruh yang sangat luar biasa dalam pengambilan keputusan, termasuk didalam industri wisata untuk mengetahui reputasi dan popularitas sebuah destinasi wisata. Saat ini penggunaan dan pemanfaatan media sosial tidak hanya sebatas media hiburan tapi juga sebagai media atau wadah untuk berbagi informasi baik informasi yang dianggap penting maupun yang tidak penting dan terabaikan. Dalam penelitian ini, kami memanfaatkan data yang tersebar melalui postingan instagram yang berkaitan dengan destinasi wisata untuk dijadikan refrensi untuk mengetahui reputasi destinasi wisata yang berada di Pulau Lombok. Data yang digunakan berasal dari Instagram dengan jumlah 600 dataset, dengan menggunakan tiga kata kunci yaitu pantai, gili dan Gunung. Adapun metode yang digunakan adalah Naive Bayes Classifier yang akan digunakan untuk mengklasifikasi postingan dan komentar instagram dengan pengklasifikasian kedalam postingan positif, negatif dan netral terhadap destinasi wisata. Hasil dari penelitian ini dapat menunjukkan bahwa akurasi naive bayes sebesar 59\%, sedangkan tempat wisata atau destinasi wisata yang dikategorikan bereputasi populer untuk pantai yaitu Pantai Kuta dengan presentase 85\% dan untuk kategori gili yaitu gili air $47 \%$ dan kategori gunung yaitu Gunung Rinjani dengan prosentase $60 \%$.
\end{abstract}

Kata Kunci: Python, Wisata, Naive Bayes Classifier.

\begin{abstract}
Social media currently has an extraordinary influence in decision making, including in the tourism industry to find out the reputation and popularity of a tourist destination. At present the use and use of social media is not only limited to entertainment media but also as a medium or a place to share information both information that is considered important or not important and neglected. In this study, we utilize data scattered through Instagram posts related to tourist destinations to be used as references to find out the reputation of tourist destinations on the island of Lombok. The data used comes from Instagram with a total of 600 datasets, using three keywords namely beach, dyke and hill. The method used is the Naive Bayes Classifier which will be used to classify postings and Instagram comments by classifying into positive, negative and neutral posts to tourist destinations. The results of this study can show that the accuracy of naive bayes is 59\%, while tourist attractions or tourist destinations which are categorized as popular for the beach are Kuta Beach with $85 \%$ percentage and for the Gili category that is $47 \%$ Gili Air namely, mountain Mount Rinjani with a percentage of $60 \%$.
\end{abstract}

Keywords: Python, Tourism, Naive Bayes Classifier.

\section{PENDAHULUAN}

$O$ ocial media saat ini telah mengubah cara orang atau masyarakat untuk berbagi dan mengunngkapkan pendapat satu dengan yang lainnya[1][2]. Sosial media saat ini telah bertransformasi menjadi aspek penting sebagai media menyebarkan informasi, mencari dan memasarkan suatu produk[3]. Sosial media juga menjadi populer seiring dengan pemerataan jaringan internet dan hadirnya platform- platform sosial media. Instagram[4].
Pengguna aktif sosial media setiap tahunnya mengalami peningkatan yang progressif. Berdasarkan data dari halaman web Hootsuite (We are social) pengguna internet aktif pada tahun 2019 sebesar 4.388 miliyar yang tersebar diseluruh dunia. Penelitian ini berfokus pada sosial media instagram[2]. Oleh sebab itu, bahkan klasifikasi otomatis sangat diperlukan untuk menangani data tersebut.

Analisis sentiment di instagram dalam prosesnya cukup rumit, disebabkan dengan adanya emotikon, kata- 
kata yang tidak baku dan kesalahan pada ejaan berdampak untuk melakukan proses preprosessing sebelum melakukan ekstraksi fitur[5]. Namun dalam penelitian sebelumnya telah dilakukan penelitian dengan menggunakan naive bayes sebagai salah satu metode yang akurat[5]. Naive bayes merupakan salah satu model probabilistik yang sederhana dan bekerja dengan baik pada proses klasifikasi teks[6]. Naive bayes banyak digunakan dan diterapkan dalam proses klasifikasi sentimen karena mampu melatih dataset menghasilkan sebuah decision atau keputusan[6][7][8][[9].

Pulau lombok merupakan salah satu destinasi wisata yang sangat banyak dikunjungi wisatawan, baik wisatawan lokal maupun wisatawan mancanegara. Pulau lombok selain dikenal sebagai pulau seribu masjid juga dikenal sebagai daerah yang kaya akan destinasi wisata alam yang menawan dan merupakan tujuan wisata halal populer di dunia. Berdasarkan data Badan Pusat Statistik (BPS) NTB tahun 2018, kunjungan wisatawan mancenegara 151.193, sedangkan wisatawan lokal mencapai 1.473.902 orang (BPS NTB) sedangkan pada akhir tahun 2018 hingga 2019 mengalami penurunan pasca bencana gempa bumi pada pertengahan 2018.

Berdasarkan data tersebut dietahui bahwa media sosial mampu menjadi salah satu refrensi untuk mengetahui popularitas destinasi wisata berdasarkan postingan pengguna di akun sosial media mereka. Pemanfaatan sosial media bisa menjadi sarana yang cukup baik dan efektif dalam peningkatan industri parawisata. Pada era teknologi informasi seperti saat ini sering dikaitkan dengan dengan yang lain termasuk dampak sosial dan ekonomi dalam rangka peningkatan kesejahteraan masyarakat lokal. Peran teknologi informasi saat ini dapat memberikan dampak positif terhadap kemajuan industri parawisata di indonesia[6]. Berdasarkan data yang bersumber dari Badan Pusat Statistik (BPS) Indonesia jumlah kunjungan wisatawan mancanegara ke indonesia pada periode januari-april 2019 mengalami kenaikan 3,22\% meskipun tidak mengalami kenaikan signifikan seperti tahun- tahun sebelumnya.

Cabang riset yang mengalami perkembangan sebagai akibat dari situasi ledakan informasi di internet adalah Sentimet Analysis. Sentiment Analysis sendiri merupakan salah satu studi komputasional dari tanggapan atau pendapat masyarakat, apresiasi dan emosi melalui entitas, event dan atribut yang dimiliki[10]. Dalam teknologi informasi saat ini muncullah dampak positif yang dihasilkan seperti memudahkan dalam hal melakukan komunikasi, mencari dan mengakses informasi. Fokus pembahasan pada penelitian ini membahas sentiment analysis untuk menentukan popularitas destinasi wisata di pulau lombok berdasarkan data Instagram. Metode yang digunakan dalam melakukan classifier sentiment adalah naive bayes classifier.

\section{STUDI PUSTAKA}

\section{A. Penelitian Terkait}

Beberapa penelitian yang membahas sentiment analysis telah dilakukan pada industri parawisata. Pada bagian ini menjelaskan perbedaan atau perbandingan dengan penelitian sebelumnya untuk membedakan inovasi yang akan dilakukan pada penelitian ini.

Beberapa diantaranya yaitu penelitian pertama [11]. Dimana didalam penelitian ini classification teknik dimasukkan kedalam domain dari blog, dan membandingkan 3 algoritma pencarian yaitu Naïve bayes, SVM dan model N-gram berbasis karakter untuk perjalan 7 negara yang ada di AS dan Eropa. Dalam kesimpulannya pendekatan SVM dan N-gram mengungguli pendekatan Naïve Bayes, dan ketika rangkaian data training memiliki banyak tinjauan, semua pendekatan yang digunakan mencapai akurasi $80 \%$.

Penelitian kedua [12] membahas mengenai perbedaan antara tempat - tempat favorit bagi turis dan penduduk local menggunakan profil dari instagram.

Peneltian ketiga [2] menjelaskan studi analisis sentimen yang dilakukan lebih dari 1000 postingan dari facebook tentang siaran berita. Dan membandingkan sentimen untuk Rai - layanan penyiaran public di italia terhadap La7 persusahaan swasta yang lebih dinamis

Penelitian keempat [13] membahas tentang sentimen manusia dari koleksi gambar yang ada diinternet dengan skala besar berdasarkan fitur dan informasi yang ada dimedia sosial kontektual (seperti : komentar teman, dan deskripsi pengguna) dengan membandingkan metode SVM dan EL dan hasilnya akurasinya meningkat $6 \%$ sampai $10 \%$.

Penelitian kelima [5] mencoba untuk menganalisis posting twitter tentang produk elektronik seperti ponsel, laptop dll, menggunakan pendekatan machine learning. Dengan melakukan analisis sentiemn dalam doman tertentu, yang dimungkinkan untuk mengidentifikasi pengaruh informasi domain dalam klasifikasi sentimen.

\section{METODE PENELITIAN}

Situs sosial media saat ini sangat diminati dan digemari diseluruh dunia, termasuk Instagram.

Dalam penelitian ini bagian metodologi akan dibahas mengenai tahap- tahap dari penelitian yang dilakukan, seperti pada gambar 1 . 


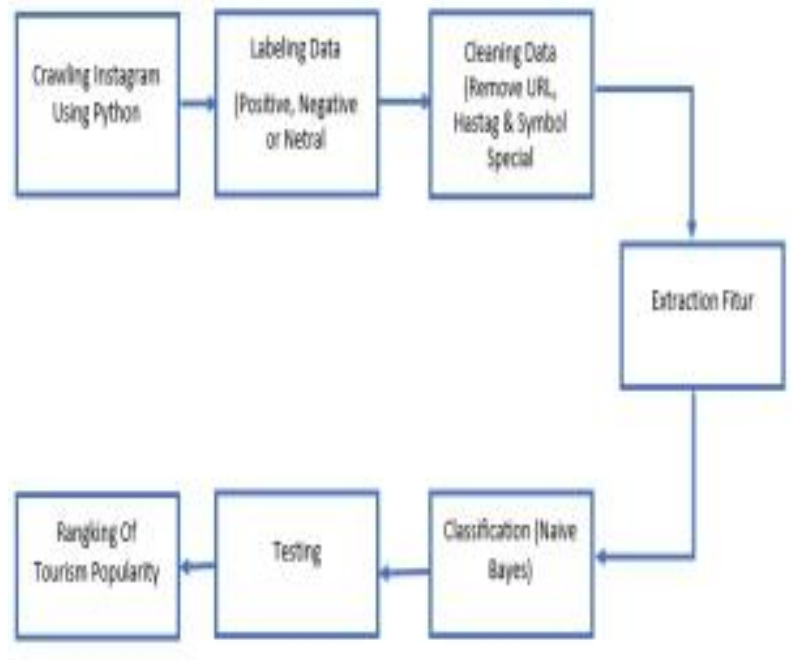

Gambar 1. Alur Penelitian

Berikut penjelasan mengenai alur penelitian tersebut:

\section{A. Mengambil Data Instagram dengan Python}

Saat mengambil data di instagram menggunakan Python tanpa menggunakan API cukup memasukkan username dan password kemudian memasukkan akun instagram untuk di Crawling datanya.

\section{B. Labeling Data}

Labeling data dilakukan terhadap data yang sudah didapatkan dengan crawling dari instagram untuk dibedakan dalam kategori positif, negatif dan netral.

\section{Cleaning Data}

Terdapat berbagai konten non sentiment seperti URL, hastag dan lain sebagainya. Data- data tersebut merupakan keluaran dari instagram dan harus dihilangkan sehingga menghasilkan sentiment yang akurat. Cleaning seperti berikut:

\section{a) Penghapusan URL}

Data instagram merupakan sumber informasi utama, dalam postingan instagram banyak pengguna yang menyertakan tautan yang tidak bisa digunakan untuk sentimen analisis, maka URL harus dihapus dari postingan.

\section{b) Penghapusan Simbol Khusus}

Penghapusan simbol- simbol khusus yang tidak bisa digunakan untuuk sentimen analisis, seperti tanda baca, angka dan lainnya.

\section{c) Penghapusan Hastag}

Penghapusan tanda hastag atau tagline, biasanya digunakan untuk memberikan nama subjek atau frasa yang popular.

\section{Ekstraksi Fitur}

Ekstraksi fitur dilakukan dalam menentukan bobot dari kalimat yang telah melewati cleaning data dengan TF-IDF.

\section{E. Nä̈ve Bayes Classifier}

Penggunaan metode Nä̈ve Bayes Classifier karena dalam penelitian ini akan melakukan proses klasifikasi, dimana Nä̈ve Bayes Classifier merupakan salah satu algoritma yang mewakili metode pembelajaran serta statistik untuk klasifikasi[14]. Metode naïve bayes classifier (NBC) memiliki Kelebihan sederhana namun memiliki akurasi yang tinggi[15]. Klasifikasi naive bayes juga mewakili metode statistik untuk klasifikasi[16]. Naive bayes juga merupakan model probabilistik dan memungkinkan untuk mendapatkan ketidakpastian tantang model algoritma probabilitas. Naïve bayes didalamnya tersedia algortima yang dapat berguna dan data yang di amati dapat dikombinasikan. Hal ini dapat membantu dalam memahami dan mengevaluasi algoritma lainnya[17]. Teorema Naive Bayes mengacu pada konsep probabilitas bersyarat[18]. Secara umum naive bayes dapat diformulakan dalam persamaan berikut[19]:

$$
(\mathrm{PAB})=\frac{P B A x P A}{P(B)}
$$

Keterangan :

PA $=$ Probabilitas Kemunculan Label

PBA = Probabilitas Kemunculan Label Terhadap fitur

Metode klasifikasi yang dapat digunakan adalah NBC (Naive Bayes Classifier). NBC memiliki kelebihan sederhana namun memiliki akuras yang cukup tinggi[15]. Didalam naive bayes classifier setiap postingan yang berupa teks pada instagram disajikan dalam pasangan atribut $\left\langle a_{1}, a_{2}, a_{3}, \ldots a_{n}\right\rangle$ dimana $a_{1}$ adalah kata pertama, $\mathrm{a}_{2}$ kata kedua dan seterusnya sampai $\mathrm{a}_{\mathrm{n}}$, sedangkan V merupakan himpunan kelas [20]. Pada saat proses klasifikasi, metode ini akan menghasilkan sebuah kategori atau kelas yang memiliki probabilitas paling tinggi $\left(\mathrm{V}_{\mathrm{MAP}}\right)$ dengan memasukkan atribut $<\mathrm{a}_{1}, \mathrm{a}_{2}$, $a_{3}, \ldots a_{n}>$. Rumus $V_{\text {MAP }}$ dapat dilihat pada persmaan berikut.

$$
\mathrm{VMAP}=\operatorname{argmaxvjeV~P~Vj~a1,a2,a3,\ldots ,an~(2)~}
$$

Dengan menggunakan teorema bayes dapat ditulis dengan formula berikut:

$$
\mathrm{V}_{\mathrm{MAP}}=\operatorname{argmax}_{\mathrm{vjeV}} \frac{P a 1, a 2,13, \ldots a n \times P V j}{P a 1, a 2, a 3, \ldots, a n}
$$

$\mathrm{P}(\mathrm{a} 1, \mathrm{a} 2, \mathrm{a} 3, \ldots, \mathrm{an})$ diberikan nilai konstan terhadap semua $\mathrm{Vj}$ sehingga persamaan 3 dapat diubah menjadi persamaan (4)

$$
\mathrm{VMAP}=\operatorname{argmaxvjeV~P~a1,a2,a3,\ldots ,an~} \mathrm{Vj} \text { x P Vj }
$$


Tabel 2. Extraction Feature

\begin{tabular}{|c|c|c|c|c|c|c|c|c|}
\hline Labelfiter & $\begin{array}{l}\text { Kenumcil } \\
\text { an Poitif }\end{array}$ & $\begin{array}{l}\text { Kemuncul } \\
\text { in Nozatif }\end{array}$ & $\begin{array}{c}\text { Kenminul } \\
\text { an Netral }\end{array}$ & $\begin{array}{c}\text { Kemancul } \\
\text { an Kasa }\end{array}$ & Dataset & Posibve & Negative & Nerd \\
\hline Lounbok & 72 & 37 & 60 & 169 & \multirow{7}{*}{600} & 0.426036 & 0.218935 & 035503 \\
\hline seneges & 60 & 10 & 22 & 92 & & 0.652174 & 0.105096 & 0.23913 \\
\hline Pantai & 89 & 29 & 29 & 147 & & 0.605442 & 0.197279 & 0.197279 \\
\hline yang & 48 & 17 & 32 & 97 & & 0.494845 & 0.175258 & 0.329897 \\
\hline beach & 42 & 7 & 13 & 62. & & 0.677419 & 0.112903 & 0.209677 \\
\hline di & 39 & 39 & 40 & 118 & & 0.330508 & \begin{tabular}{|l|}
0.330506 \\
\end{tabular} & \begin{tabular}{|l}
0.338983 \\
\end{tabular} \\
\hline pitik & 32 & 9 & 15 & $\$ 6$ & & 0.571429 & $0.160^{7} 14$ & 0.267857 \\
\hline
\end{tabular}

Berdasarkan tabel 2, diketahui bahwa berdasarkan dataset kata lombok yang muncul 169 kali, dimana 72 berlabel positif, 60 Netral dan 37 berlabel negatif dengan probabilitas kemunculan kata sebesar 0.42 atau $42 \%$ untuk label positif, 0.21 , atau $21 \%$ probabiltas pada kata negatif, dan 0.35 atau $35 \%$ untuk yang berlabel netral. Hal yang sama dapat juga dilakukan untuk kata kunci gili dan gunung.

\section{E. Classfication Nä̈ve Bayes}

Selanjutnya tahap neive bayes dilakukan dengan beberapa tahap atau proses, yaitu:

\section{Pengumpulan Data}

Tahap ini dilakukan proses pengumpulan data yang akan dilakukan klasifikasi, terlihat pada gmbar berikut:

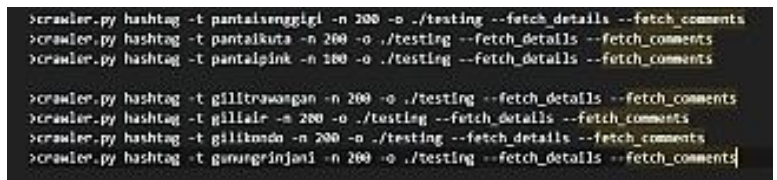

Gambar 5. Pengumpulan data testing

Gambar 5 diatas merupakan perintah yang digunakan untuk proses pengumpulan data testing, setiap kata kunci dibatasi sebanyak 200 data.

\section{Klasifikasi Pantai, Gili dan Gunung}

Dalam proses ini digunakan 5 kata kunci yang terkait pantai 3 kata kunci dan gili 1 kata kunci dan gunung 1 kata kunci yang akan digunakan untuk mengumpulkan data dan selanjutnya data tersebut akan melewati proses klasifikasi dengan naive bayes, seperti yang disajikan pada tabel 3 berikut:

Tabel 3 Kata Kunci

\begin{tabular}{|l|l|l|}
\hline Kata Kunci & Jenis & Jumlah Data \\
\hline Pantai Senggigi & Pantai & 128 \\
\hline Pantai Kuta & Pantai & 80 \\
\hline Pantai Pink & Pantai & 48 \\
\hline Gili Trawangan & Gili & 79 \\
\hline Gunung Rinjami & Gunung & 83 \\
\hline
\end{tabular}

Berdasarkan tabel 3 diatas menunjukkan bahwa jumlah postingan instagram pantai senggigi dan gili trawangan merupakan destinasi wisata terpopuler dengan msing- masing 128 postingan untuk pantai senggigi dan 79 postingan untuk gili trawangan dan 82 postingan untuk gunung rinjani dari proses pencarian data.

\section{Klasifikasi Sentiment menggunakan naïve bayes}

Pada proses ini dilakukan klasifikasi sentiment dengan menggunakan naïve bayes, berikut hasil klasifikasi masing- masing kata kunci dengan naïve bayes, berikut kode program yang digunakan seperti pada gambar 6.

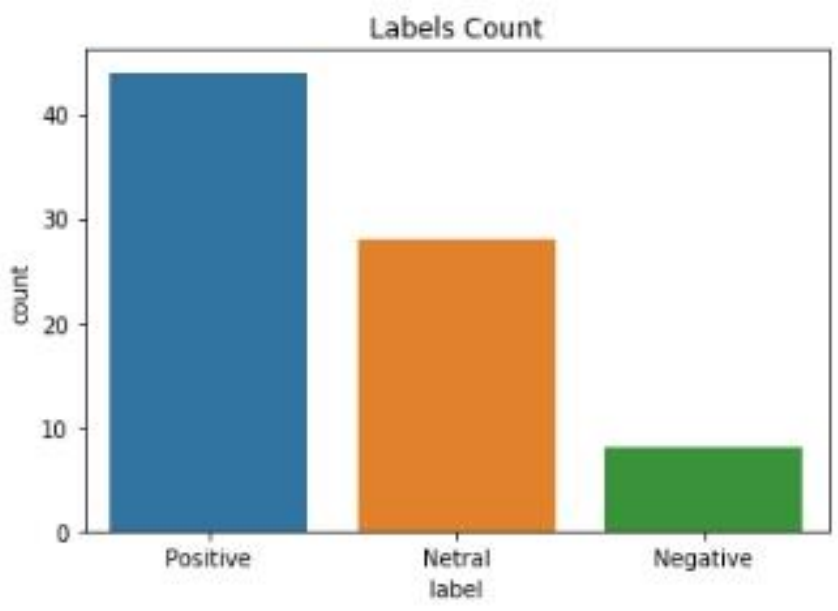

Gambar 6. Hasil Klasifikasi

Gambar 5 merupakan contoh hasil klasifikasi pada data set pantai senggigi, dari 128 data, 45 postingan postitive, 29 netral dan 9 postingan negative.

Sedangkan untuk hasil akurasi, presisi, recall dan F1-Score untuk percobaan klasifikasi pantai senggigi dengan Naïve Bayes seperti ditunjukkan kode program pada gambar 7 berikut.

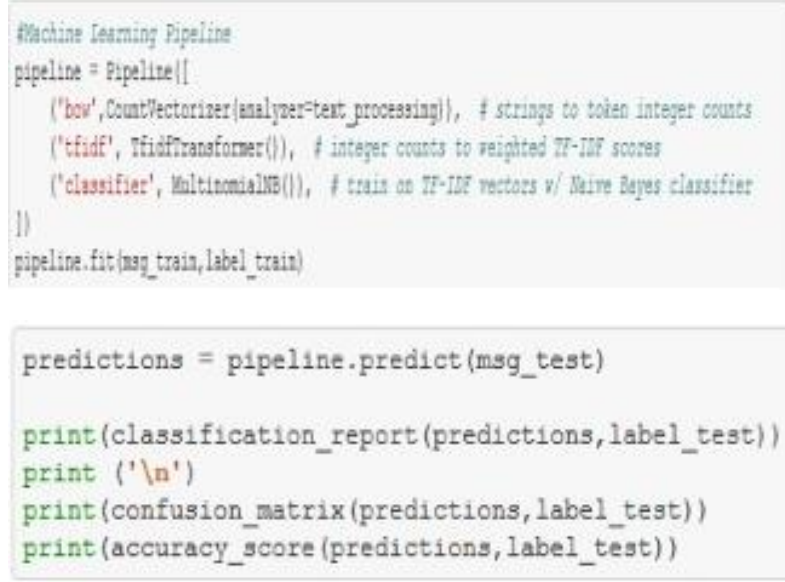

Gambar 7. Kode Program Akurasi, Presisi, Recall F1Score

Hasil akurasi, presisi, recall dan F1-Score untuk percobaan klasifikasi Pantai Senggigi dengan Naïve Bayes seperti pada gambar 8 berikut. 


$\begin{array}{rrrr} & \text { precision } & \text { recall } & \text { f1-score } \\ \text { Netral } & 0.25 & 0.20 & 0.22 \\ \text { Positive } & 0.67 & 0.73 & 0.70 \\ \text { accuracy } & & & 0.56\end{array}$

Gambar 8. Hasil Akurasi, Presisi, Recall F1-Score

Berdasarkan hasil diatas di tunjukkan bahwa nilai akurasinya untuk wisata pantai senggigi sebesar $56 \%$.

\section{Testing}

Tahapan testing dilakukan sehingga hasilnya dapat menunjukkan dari sentiment positive, negative dan netral dari setiap kata kunci pantai, gili dan gunung.

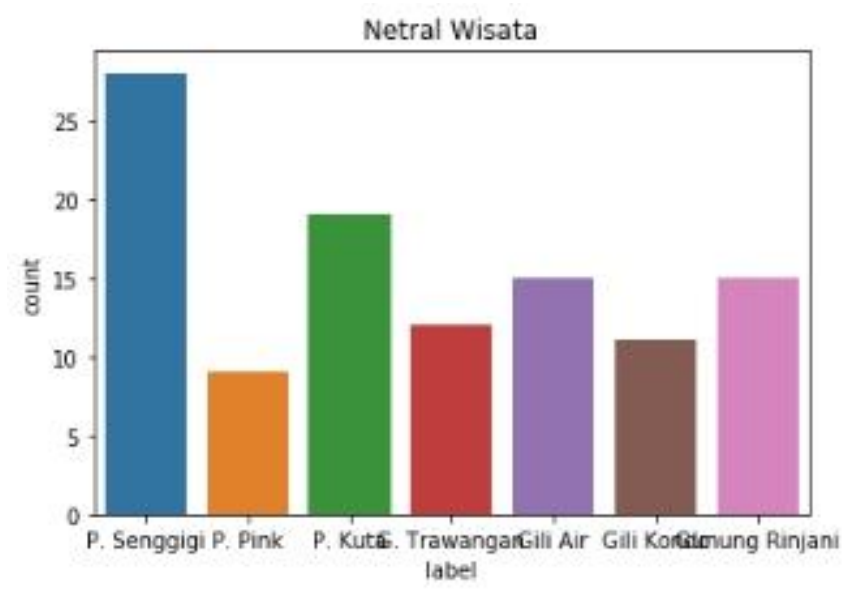

Gambar 9. Sentiment Netral

Gambar 9 diatas menunjukkan hasil sentiment netral dengan kata kunci pantai, gili dimana ditunjukkan hasil sentiment netral tertinggi yaitu pantai senggigi dan sentimen netral terendah pantai pink.

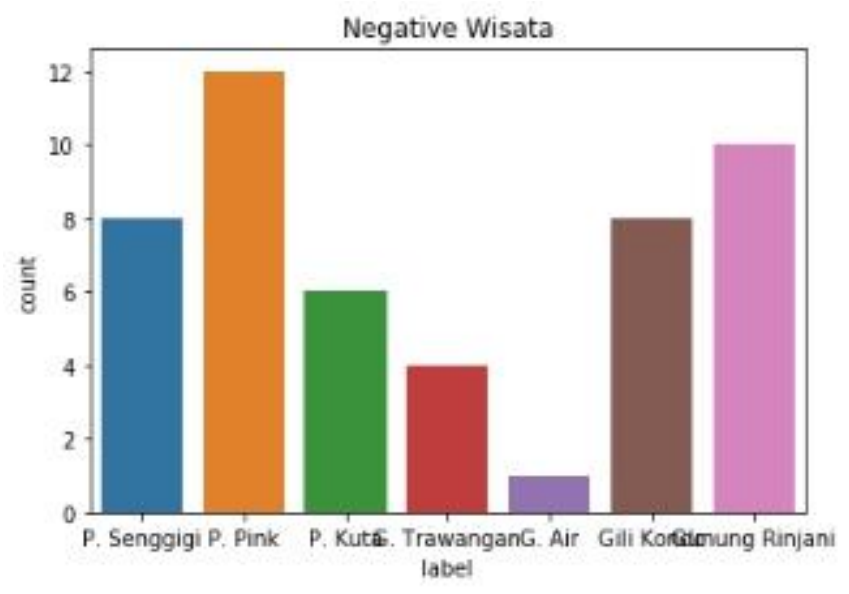

Gambar 10. Sentiment Negative

Gambar 10 merupakan hasil sentiment negative dari instagram, dimana pantai pink memiliki sentiment negative tertinggi dan Gili air paling rendah sentiment negativenya.

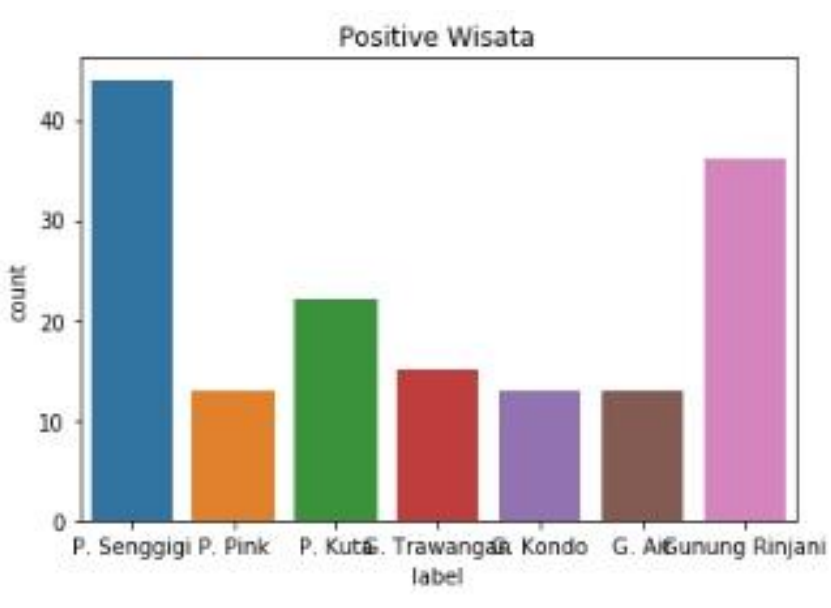

Gambar 11. Sentiment Positive

Gambar 11 diatas menunjukkan hasil sentiment positive dari pantai, gili dan gunung, dimana pantai senggigi menjadi destinasi yang memiliki sentiment positive tertinggi dan pantai terendah pantai pink.

Tahap selanjutnya adalah tahap pengujian, hasil tahap pengujian dapat dilihat pada table 3 di bawah ini:

Table 4. perbandingan manual vs aplikasi

\begin{tabular}{|l|l|l|l|}
\hline \multicolumn{1}{|c|}{ Kalimat } & $\begin{array}{c}\text { Hasil } \\
\text { Ap- } \\
\text { likasi }\end{array}$ & $\begin{array}{c}\text { Hasil } \\
\text { Man- } \\
\text { ual }\end{array}$ & $\begin{array}{c}\text { Keco- } \\
\text { cokan }\end{array}$ \\
\hline $\begin{array}{l}\text { Menikmati keinda- } \\
\text { han pantai dengan } \\
\text { angin semilir mem- } \\
\text { buat ku semakin } \\
\text { bersyukur akan cip- } \\
\text { taanNya }\end{array}$ & Positive & $\begin{array}{l}\text { Posi- } \\
\text { tive }\end{array}$ & True \\
\hline $\begin{array}{l}\text { Senggigi, Guru ter- } \\
\text { baik adalah alam, } \\
\text { setiap petualangan } \\
\text { pasti akan } \\
\text { mengajarkan } \\
\text { sesuatu yang ber- } \\
\text { nilai kepadamu. }\end{array}$ & Netral & $\begin{array}{l}\text { Posi- } \\
\text { tive }\end{array}$ & False \\
\hline $\begin{array}{l}\text { Pantai Pink berpasir } \\
\text { putih, rumput hijau, } \\
\text { dan air berwarna } \\
\text { biru. Lalu dari } \\
\text { mana pink nya? }\end{array}$ & Netral & Netral & True \\
\hline $\begin{array}{l}\text { Angkernya GOA } \\
\text { JEPANG di Pantai } \\
\text { Pink Lombok. }\end{array}$ & $\begin{array}{l}\text { Nega- } \\
\text { tive }\end{array}$ & $\begin{array}{l}\text { Nega- } \\
\text { tive }\end{array}$ & True \\
\hline
\end{tabular}

Tabel 4 diatas merupakan contoh hasil pengujian dengan membandingkan klasifikasi manual dan klasifikasi dengan aplikasi. Hasil perbandingan terhadap seluruh dataset sebagai berikut: 
Tabel 5. Pengujian

\begin{tabular}{|c|c|c|c|c|}
\hline \multirow[t]{2}{*}{$\begin{array}{c}\text { Ob- } \\
\text { jek Wisata }\end{array}$} & \multicolumn{3}{|c|}{$\begin{array}{l}\text { Jumlah Pelabelan ap- } \\
\text { likasi dan manual }\end{array}$} & \multirow{2}{*}{$\begin{array}{l}\text { Nilai Akurasi } \\
\text { (keco- } \\
\text { cokan/semua } \\
\text { data) }\end{array}$} \\
\hline & $\begin{array}{l}\text { Posi- } \\
\text { tif }\end{array}$ & Negatif & $\begin{array}{l}\mathrm{Ne}- \\
\text { tral }\end{array}$ & \\
\hline $\begin{array}{l}\text { Pantai } \\
\text { Senggigi }\end{array}$ & 45 & 8 & 29 & $/ 128$ \\
\hline $\begin{array}{l}\text { Pantai } \\
\text { Kuta }\end{array}$ & 22 & 5 & 19 & 180 \\
\hline $\begin{array}{l}\text { Pantai } \\
\text { Pink }\end{array}$ & 13 & 12 & 9 & 148 \\
\hline $\begin{array}{l}\text { Gili Tra- } \\
\text { wangan }\end{array}$ & 15 & 4 & 12 & 179 \\
\hline $\begin{array}{l}\text { Gili } \\
\text { Kondo }\end{array}$ & 13 & 8 & 11 & 60 \\
\hline Gili Air & 13 & 1 & 15 & 156 \\
\hline $\begin{array}{l}\text { Gunung } \\
\text { Rinjami }\end{array}$ & 35 & 10 & 15 & 183 \\
\hline Total & & & $314 / 5$ & \\
\hline Akurasi & & & $588=$ & \\
\hline
\end{tabular}

\section{Perangkingan}

Tahapan perangkingan merupakan tahap terakhir untuk mencari destinasi wisata popular di pulau Lombok seperti yang ditunjukkan gambar 12 berikut.

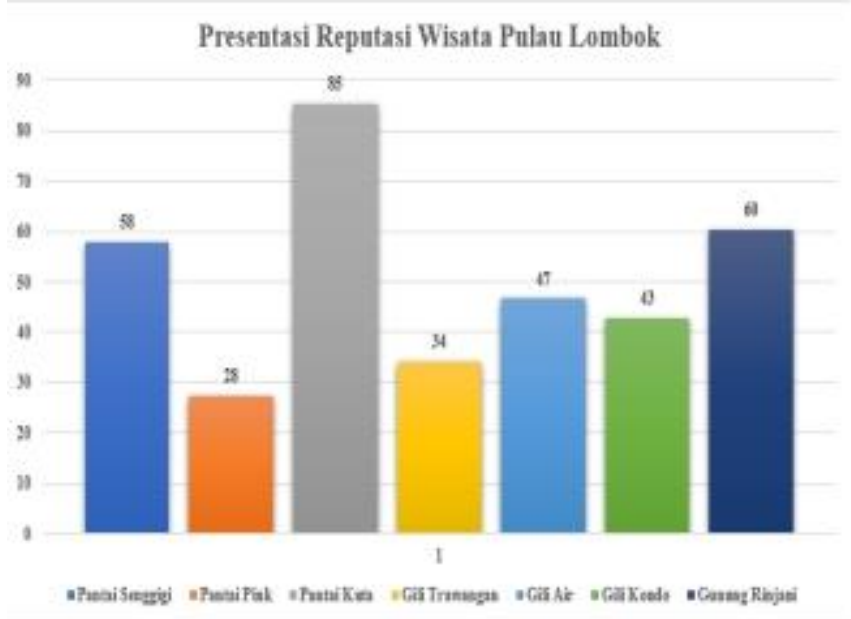

Gambar 12. Rangking Reputasi Wisata

Gambar 12 diatas menunjukkan hasil presentase reputasi destinasi wisata di pulau Lombok dengan kata kunci pantai, gili dan gunung, dimana untuk memperoleh nilai pada masing- masing destinasi dengan menjumlahkan label postif dijumlahkan dengan label netral dan dibagi jumlah postingan masing- masing destinasi wisata atau dengan menggunakan formula:

$$
\text { Presntase }=\frac{\text { Label Positif }+ \text { Label Netral }}{\text { Jumlah Postingan }} \quad x 100
$$

Berdasarkan grafik pada gambar 12 menunjukkan bahwa destinasi wisata yang memiliki presentasi tertinggi adalah pantai kuta dengan $85 \%$, kemudian gunung rinjani dengan $60 \%$. Berikut peringkat reputasi wisata pantai, gili dan gunung di pulau Lombok pada table 6.

Table 6. Rangking Reputasi Destinasi Wisata

\begin{tabular}{|c|c|c|}
\hline Jenis & Destinasi & Peringkat \\
\hline Pantai & Kuta & 1 \\
\cline { 2 - 3 } & Senggigi & 2 \\
\cline { 2 - 3 } & Pink & 3 \\
\hline \multirow{3}{*}{ Gili } & Air & 1 \\
\cline { 2 - 3 } & Kondo & 2 \\
\cline { 2 - 3 } & Trawangan & 3 \\
\hline Gunung & Rinjani & 1 \\
\hline
\end{tabular}

\section{KeSIMPULAN}

Berdasarkan analisis data yang telah peneliti lakukan dengan memanfaatkan data Instagram untuk mencari destinasi wisata yang memiliki reputasi popular di pulau Lombok menggunakan kata kunci pantai, gili dan gunung dengan menggunakan Naïve Bayes Classifier. Dialam penelitian tersebut didapatkan akurasi naïve bayes sebesar 59\%, dimana tempat wisata yang termasuk tempat wisata dengan reputasi popular untuk kategori pantai adalah Pantai Kuta, sedangkan untuk gili adalah Gili Air dan untuk kategori gunung adalah Gunung Rinjani.

\section{DAFTAR PUSTAKA}

[1] Y. Mejova, "Sentiment Analysis : An Overview Comprehensive Exam Paper," Science (80-. )., pp. 1-34, 2009.

[2] F. Neri, C. Aliprandi, F. Capeci, M. Cuadros, and T. By, "Sentiment analysis on social media," Proc. 2012 IEEE/ACM Int. Conf. Adv. Soc. Networks Anal. Mining, ASONAM 2012, pp. 919-926, 2012, doi: 10.1109/ASONAM.2012.164.

[3] K. Lerman and R. Ghosh, "Information contagion: An empirical study of the spread of news on Digg and Twitter social networks," ICWSM 2010 - Proc. 4th Int. AAAI Conf. Weblogs Soc. Media, pp. 90-97, 2010.

[4] E. Jean and P. Ed, "Local and Global Responses to Disaster: \# eqnz and the Christchurch Earthquake Associate Professor Axel Bruns ARC Centre of Excellence for Creative Industries \& Innovation Queensland University of Technology , Brisbane, Australia ARC Centre of Excellenc," Disaster Emerg. Manag. Conf. Conf. Proc., pp. 86-103, 2012.

[5] M. S. Neethu and R. Rajasree, "Sentiment analysis in twitter using machine learning techniques," 2013 4th Int. Conf. Comput. Commun. Netw. Technol. ICCCNT 2013, 2013, doi: 10.1109/ICCCNT.2013.6726818.

[6] V. Narayanan, I. Arora, and A. Bhatia, "Fast and accurate sentiment classification using an enhanced Naive 
Bayes model," Lect. Notes Comput. Sci. (including Subser. Lect. Notes Artif. Intell. Lect. Notes Bioinformatics), vol. 8206 LNCS, pp. 194-201, 2013, doi: 10.1007/978-3-642-41278-3_24.

[7] P. Chesley, B. Vincent, L. Xu, and R. K. Srihari, “Using verbs and adjectives to automatically classify blog sentiment," AAAI Spring Symp. - Tech. Rep., vol. SS-06-03, pp. 27-29, 2006.

[8] M. Gamon, A. Aue, S. Corston-Oliver, and E. Ringger, "Pulse: Mining customer opinions from free text," Lect. Notes Comput. Sci. (including Subser. Lect. Notes Artif. Intell. Lect. Notes Bioinformatics), vol. 3646 LNCS, pp. 121-132, 2005, doi: 10.1007/11552253_12.

[9] "SENTIMENT CLASSIFICATION OF MOVIE REVIEWS USING LINGUISTIC PARSING Brian Eriksson CS 838 - Natural Language Processing Final Project Report," pp. 4-9.

[10] Liu.B, Opinion Mining. Chicago, United States of America, 2012.

[11] Q. Ye, Z. Zhang, and R. Law, "Sentiment classification of online reviews to travel destinations by supervised machine learning approaches," Expert Syst. Appl., vol. 36, no. 3 PART 2, pp. 6527-6535, 2009, doi: 10.1016/j.eswa.2008.07.035.

[12] K. D. Mukhina, S. V. Rakitin, and A. A. Visheratin, "Detection of tourists attraction points using Instagram profiles," Procedia Comput. Sci., vol. 108, no. June, pp. 2378-2382, 2017, doi: 10.1016/j.procs.2017.05.131.

[13] Y. Wang and B. Li, "Sentiment Analysis for Social Media Images," Proc. - 15th IEEE Int. Conf. Data Min. Work. ICDMW 2015, pp. 1584-1591, 2016, doi: 10.1109/ICDMW.2015.142.

[14] A. Sinaga, "Implementasi Sentiment Analysis untuk Menentukan Tingkat Popularitas Tujuan Wisata," Pros. Semin. Nas. Teknol. dan Rekayasa Inf. Tahun 2017, no. November, pp. 24-25, 2017.

[15] I. Rish, "An empirical study of the naive Bayes classifier," Phys. Chem. Chem. Phys., vol. 3, no. 22, pp. 4863-4869, 2001, doi: 10.1039/b104835j.

[16] M. Murnawan, "Pemanfaatan Analisis Sentimen Untuk Pemeringkatan Popularitas Tujuan Wisata," $J$. Penelit. Pos dan Inform., vol. 7, no. 2, p. 109, 2017, doi: 10.17933/jppi.2017.070203.

[17] J. Ren, S. D. Lee, X. Chen, B. Kao, R. Cheng, and D. Cheung, "Naive bayes classification of uncertain data," Proc. - IEEE Int. Conf. Data Mining, ICDM, no. 60703110, pp. 944-949, 2009, doi: 10.1109/ICDM.2009.90.

[18] E. W. Sandi Fajar Rodiyansyah, "Klasifikasi Posting Twitter Kemacetan Lalu Lintas Kota Bandung Menggunakan Naive Bayesian Classification," IJCCS, vol. Vol. 6, No.

[19] J. Han and M. Kambe, Data Mining: Concepts and Techniques 2e, 2E ed. San Fransisco: Morgan Kaufmann Publishers, 2006.

[20] and H. S. C. D. Manning, P. Raghavan, Introduction to Information Retrieval. California: Cambridge University Press, 2008.
[21] K. Tan, Steinbach, Karpatne, "Data Mining: Data Lecture Notes for Chapter 2 Introduction to Data Mining by What is Data?," Ratio, 2004. 